\title{
UPAYA MENINGKATKAN HASIL BELAJAR MATEMATIKA \\ DENGAN MENGGUNAKAN MODEL PROBLEM BASED LEARNING (PBL) DAN BERBANTUAN MEDIA KARTU PECAHAN PADA PESERTA DIDIK KELAS V/B \\ SDN-2 BUKIT TUNGGAL PALANGKARAYA \\ TAHUN PELAJARAN 2017/2018
}

\section{Oleh: NIDDIA JAYANTI* Dedy Setyawan, M.Pd}

\begin{abstract}
ABSTRAK
Penelitian ini bertujuan untuk mengetahui: (1) Aktivitas peserta didik dalam belajar matematika dengan menerapkan model pembelajaran Problem Based Learning (PBL) dan berbantuan media kartu pecahan pada kelas V/B SDN-2 Bukit Tunggal Tahun Pelajaran 2017/2018. (2) Peningkatan hasil belajar matematika dengan menerapkan model pembelajaran Problem Based Learning (PBL) dan berbantuan media kartu pecahan pada kelas V/B SDN-2 Bukit Tunggal Tahun Pelajaran 2017/2018.

Subjek penelitian ini adalah peserta didik kelas V/B SDN-2 Bukit Tunggal yang berjumlah 21 orang peserta didik, yaitu laki-laki 13 orang peserta didik dan perempuan 8 orang peserta didik. Jenis penelitian ini adalah Penelitian Tindakan Kelas (PTK). Teknik pengumpulan data yang digunakan yaitu observasi dan tes. Analisis data yang digunakan yaitu analisis kualitatif dan kuantitatif.

Hasil penelitian ini menunjukan bahwa: (1) Ada peningkatan aktivitas belajar Matematika dengan menggunakan model Problem Based Learning (PBL) dan Berbantuan Media Kartu Pecahan pada peserta didik kelas V/B SDN-2 Bukit Tunggal Palangka Raya menjadikan peserta didik menjadi baik. Pada siklus I skor yang diperoleh 2,80 dengan kategori cukup, meningkat pada siklus II menjadi 3,74 dengan kategori baik. (2) Ada peningkatan hasil belajar Matematika peserta didik kelas V/B SDN-2 Bukit Tunggal Palangka Raya dengan menggunakan model Problem Based Learning (PBL) dan Berbantuan Media Kartu Pecahan, hal ini dapat dilihat dari tes awal diperoleh nilai rata-rata 44,76 dengan ketuntasan klasikal $38,09 \%$, siklus I diperoleh nilai rata-rata 66,19 dengan ketuntasan klasikal 61,90\% dan pada siklus II diperoleh nilai rata-rata 91,42 dengan ketuntasan klasikal 100\%.

Kata Kunci : Hasil Belajar, Matematika, Model Problem Based Learning (PBL) Dan Berbantuan Media Kartu Pecahan.

$\begin{array}{rlr}\text { PENDAHULUAN } & 1945 \text { yang berakar pada nilai-nilai } \\ \text { Pendidikan nasional adalah } & \text { agama, kebudayaan nasional } \\ \text { pendidikan yang berdasarkan } & \text { Indonesia dan tanggap terhadap } \\ \text { Pancasila dan Undang-undang Dasar } & \text { tuntutan perubahan zaman. Meunurut } \\ \text { Negara Republik Indonesia Tahun } & \text { Pasal 1 ayat } 2 \text { (UURI, No.20/2003) }\end{array}$
\end{abstract}


menyatakan bahwa "Pendidikan Nasional adalah pendidikan yang berdasarkan Pancasila dan Undangundang Dasar Negara Republik Indonesia tahun 1945 yang berakar pada nilai-nilai agama, kebudayaan nasional Indonesia, dan tanggap terhadap tuntutan zaman".

Pembelajaran adalah proses interaksi peserta didik dengan pendidik dan sumber belajar pada suatu lingkungan belajar yang meliputi guru dan peserta didik yang saling bertukar informasi. Tujuan pembelajaran adalah perilaku hasil belajar yang diharapkan terjadi, dimiliki, atau dikuasai oleh peserta didik setelah mengikuti kegiatan pembelajaran tertentu.

Dimana kita ketahui bahwa matematika merupakan mata pelajaran yang bersifat abstrak sehingga dituntut kemampuan guru untuk dapat menggunakan metode, model, strategi ataupun pendekatan yang tepat sesuai tingkat perkembangan mental peserta didik. Untuk itu, diperlukan model dan media pembelajaran yang dapat membantu peserta didik untuk mencapai kompetensi dasar dan indikator pembelajaran.

Guru memegang peran penting dalam tercapai atau tidaknya tujuan pembelajaran di kelas. Guru merupakan tenaga profesional yang harus dapat merencanakan, melaksanakan pembelajaran, menilai hasil pembelajaran, melakukan bimbingan, serta penelitian dan pengabdian pada masyarakat. Guru yang kompeten dan profesional dituntut untuk terus-menerus berupaya mengorganisasikan kelasnya sedemikian rupa sehingga berlangsung menyenangkan dan tujuan dapat tercapai dengan hasil yang memuaskan.

Untuk mencapai tingkat pertumbuhan dan perkembangan yang diharapkan pada diri peserta didik maka guru harus memperhatikan keadaan individu, seperti : minat, kemampuan, dan latar belakangnya. Keadaan-keadaan tersebut tentu berbeda antara satu peserta didik dengan lainnya. Di sisi lain guru merancang kegiatankegiatan belajar dan bahan pelajaran yang serasi dengan keadaan tadi. Jangan sampai kegiatan dan bahanbahan belajar justru menimbulkan rasa takut atau mematikan minat para peserta didik secara perorangan. Kemampuan seperti ini mutlak diperlukan agar tujuan pembelajaran tercapai maksimal.

Peneliti melakukan observasi pada hari sabtu tangga 06 Januari 2018, pada pukul 08.00 WIB, di sekolah SDN 2 Bukit Tunggal yaitu dikelas V/B. Dimana masih ada peserta didik yang masih kesulitan dalam belajar matematika. Dan juga disini peneliti juga melihat masih ada peserta didik yang tidak memperhatikan penjelasan di depan di saat pembelajaran. Peserta didik yang tidak memperhatikan penjelasan di depan itu karena asik dengan urusan mereka masingmasing. Masih ada peserta didik 
yang main sendiri, berbicara dengan teman sebelahnya dan lain-lain.

Saat peneliti melakukan observasi di SDN-2 Bukit Tunggal Palangka Raya, adapun hasil wawancara peneliti dengan guru yaitu masih ada peserta didik yang mendapatkan nilai yang dibawah rata-rata standar keputusan sekolah. Dari seluruh kelas V/B SDN-2 Bukit Tunggal Palangka Raya yang berjumlah 21 orang peserta didik dari $20 \%$ atau sebanyak 7 orang peserta didik yang memperoleh nilai di atas stadar. Sedangkan $80 \%$ atau sebanyak 14 orang peserta didik yang memperoleh nilai dibawah standar ketuntasan (KKM). Adapun nilai standar ketuntasan yang ditentukan sekolah untuk mata pelajaran Matematika adalah 60 .

Ada beberapa faktor yang mempengaruhi hasil belajar peserta didik diantaranya adalah kurangnya variasi model dalam pembelajaran berlangsung sehingga kurang adanya keaktifan dan minat dalam mengikuti pembelajaran. Sehingga pada saat pembelajaran matematika peserta didik kurang memperhatikan pembelajaran dan asik dengan urusan mereka sendiri.

Kurangnya bantuan media dalam pembelajaran pada mata pelajaran Matematika juga mempengaruhi dalam materi pecahan pada peserta didik kelas V/B di SDN-2 Bukit Tunggal Palangka Raya untuk meningkatkan hasil belajar peserta didik. Maka dari itu, untuk menumbuhkan niat belajar pada peseta didik perlu adanya sebuah model dengan berbantuan media untuk meningkatkan hasil belajar. Karena hasil belajar yang kurang efektif akan mempengaruhi belajar peserta didik dalam pembelajaran.

Penelitian ini sangat penting karena dilihat dari hasil belajar Matematika peserta didik yang belum mencapai standar. Hal ini akan berakibat pada pemahaman peserta didik tentang materi yang sudah disampaikan tersebut pada materi yang akan di pelajari selanjutnya.

Berdasarkan fenomena tersebut yang telah terjadi di SDN-2 Bukit Tunggal Palangkaraya maka peneliti tertarik untuk melakukan penelitian dengan judul "Upaya Meningkatkan Hasil Belajar Matematika Dengan Menggunakan Model Problem Based Learning (PBL) Dan Berbantuan Media Kartu Pecahan Pada SDN-2 Bukit Tunggal Palangkaraya".

Menurut H.S.Barrows (Kartini NH, 2017:34) menyatakan bahwa "PBL adalah sebuah metode pembelajaran yang didasarkan pada prinsip bahwa masalah (problem) dapat digunakan sebagai titik awal untuk mendapatkan atau mengintegrasikan ilmu (knowledge) baru".Menurut Barr dan Tagg (Huda Miftahul, 2013:271) menyatakan bahwa "PBL merupakan salah satu bentuk peralihan dari paradigma pengajaran menuju paridigma pembelajaran".

Jadi kesimpulan menurut para ahli diatas adalah "Problem Based Learning (PBL) merupakan 
pembelajaran yang bercirikan adanya permasalahan untuk peserta didik memecahkan masalah yang ada di suatu pembelajaran".

Langkah-langkah pelaksanaan

Menurut Huda Miftahul, (2013:271) yaitu:

a. Identifikasikan suatu masalah yang cocok bagi para peserta didik

b. Kaitkan masalah tersebut dengan konteks dunia peserta didik sehingga mereka dapat menghadirkan suatu kesempatan otentik

c. organisasikan pokok bahasan kepada suatu masalah. Berilah para peserta didik tanggung jawab untuk dapat mendefenisikan sendiri pengalaman belajar mereka serta membuat perencanaan dalam penyelesaian masalah

d. berikan dukungan kepada semua peserta didik untuk mendemonstrasikan hasil-hasil pembelajaran mereka misalnya dalam bentuk suatu karya atau kinerja tertentu.

Kelemahan Huda Miftahul, (2013:271) yaitu:

a. Siswa didorong untuk memilikib. kemampuan memecahkan masalah dalam situasi nyata.

b. Siswa memiliki kemampuan membangun pengetahuannya sendiri melalui aktifitas belajar.

c. Pembelajaran berfokus pada masalah sehingga materi yang tidak ada hubungannya tidak perlu dipelajari oleh siswa. Hal ini mengurangi beban siswa dengan menghafal atau meyimpan informasi.

d. Terjadi aktivitas ilmiah pada siswa melalui kerja kelompok.

e. Siswa terbiasa menggunakan sumber-sumber pengetahuan, baik dari perpustakaan, internet, wawancara dan observasi.

f. Siswa memiliki kemampuan menilai kemajuan belajarnya sendiri.

g. Siswa memiliki kemampuan untuk melakukan komunikasi ilmiah dalam kegiatan diskusi atau presentasi hasil pekerjaan mereka.

h. Kesulitan belajar siswa secara individual dapat diatasi melalui kerja kelompok dalam bentuk peer teaching.

Kelemahan Huda Miftahul, (2013:272) yaitu:

a. PBM tidak dapat diterapkan untuk setiap materi pelajaran, ada bagian guru berperan aktif dalam menyajian materi. PBM lebih cocok untuk pembelajaran yang menuntut kemampuan tertentu yang kaitannya dengan pemecahan masalah.

Dalam suatu kelas yang memiliki tingkat keragaman siswa yang tinggi akan terjadi kesulitan dalam pembagian tugas.

Menurut Rufaidlilah Kartika (2012:36) mengatakan bahwa :

Kartu bilangan adalah yang berfungsi untuk menambah keterampilan siswa dalam memahami atau mendalami suatu materi yang konsepnya telah dipelajari. Salah 
satu contoh alat peraga kartu pecahan adalah kartu permainan pecahan. Alat peraga kartu permainan pecahan ini berguna untuk membina keterampilan siswa dalam mengubah pecahan biasa menjadi pecahan desimal dan sebaliknya. Setiap kartu mempunyai dua bagian yang berbeda yaitu satu bagian berisi pecahan biasa dan satu bagian berisi pecahan desimal.

$$
\text { Menurut }
$$

Sudirman (Sundayana, 2015:75) mengatakan bahwa: Kartu pecahan merupakan media pembelajaran matematika yang dapat membantu siswa untuk memahami materi pecahan. Kartu pecahan dilengkapi dengan gambar kartun atau animasi yang disukai oleh siswa dan juga terdapat katakata motivasi sehingga siswa menjadi semangat untuk belajar.

Jadi kesimpulan dari para ahli di atas menyatakan bahwa "Media kartu pecahan merupakan salah satu jenis media kartu bilangan. Media kartu pecahan adalah media pembelajaran yang digunakan untuk membantu guru dalam menjelaskan konsep pecahan sederhana dengan kompetensi dasar membandingkan pecahan sederhana".

Adapun langkah-langkah dalam menggunakan media kartu pecahan adalah sebagai berikut:

a. Guru menjelaskan materi pembelajaran tentang pecahan

b. Guru memberikan sebuah contoh tentang pecahan

c. Peserta didik di bagi menjadi 7 kelompok d. Peserta didik diberikan masingmasing 2 kartu perkolompok

e. Guru memberikan sebuah pertanyaan tentang pecahan, dan peserta didik mencari jawaban dari pertanyaan yang mana jawaban tersebut terdapat dikartu yang telah dibagikan.

f. Kelompok yang dapat menjawab akan mendapatkan 1 buah bintang dari guru.

g. Dan kelompok yang paling banyak menjawab atau yang banyak mendapat bintang akan menjadi pemenang.

Adapun kekurangan daam media kartu pecahan adalah :

a. Bahannya murah

b. Mudah diperoleh

c. Peserta didik dapat menggunakannya langsung

d. Dapat menarik minat peserta didik Adapun kekurangan daam media kartu pecahan adalah

a. Tidak dapat menampilkan objek atau benda yang terlalu besar

b. Ukurannya terlalu kecil untuk ditampilkan secara klasikal.

\section{METODOLOGI PENELITIAN}

Penelitian ini dilaksanakan dengan menggunakan metode

Penelitian Tindakan Kelas (Classroom action research). Menurut Kunandar (2011:42) "Penelitian Tindakan Kelas merupakan bagian dari penelitian tindakan (action research), dan penelitian tindakan ini bagian dari penelitian pada umumnya". 
Sedangkan menurut Arikunto (2012:58) "Penelitian Tindakan Kelas adalah penelitian tindakan (action research) yang dilakukan dengan tujuan memperbaiki mutu praktik pembelajaran di kelasnya".Berdasarkan pendapat di atas maka dapat disimpulkan bahwa "Penelitian Tindakan Kelas adalah cara untuk memperbaiki mutu praktik pembelajaran".

Penelitian Tindakan Kelas ini berfokus pada upaya untuk mengubah kondisi sekarang ke arah kondisi yang diharapkan. Secara ringkas, Penelitian Tindakan Kelas adalah bagaimana sekolompok guru dapat mengorganisasikan kondisi praktek pembelajaran mereka, dan belajar dari pengalaman mereka sendiri. Mereka dapat mencobakan suatu gagasan perbaikan dalam praktek pembelajaran mereka, dan melihat pengaruh nyata dari upaya itu. Selain itu, Penelitian Tindakan Kelas juga penelitian yang refleksi yang dilaksanakan secara siklis (berdaur) dimulai dari tahapan perencanaan, tindakan, pengamatan, dan refleksi untuk memecahkan masalah dan mencobakan hal-hal baru demi peningkatan kualitas pembelajaran.

Jenis penelitian ini melalui siklus, di mana masing-masing siklus terdiri dari 4 tahapan, yaitu:

1. Perencanaan

2. Pelaksanaan tindakan

3. Observasi

4. Refleksi
Dalam hal ini peneliti menggunakan alat peraga sebagai media yang digunakan untuk pembelajaran matematika kelas V/B SDN 2 Bukit Tunggal. Adapun yang di teliti adalah hasil belajar peserta didik.

Peran dan partisipasi peneliti dalam penelitian sangatlah penting karena peneliti mutlak diperlukan pada setiap kegiatan ditempat penelitian dikarenakan peneliti berperan sebagai perencana, pelaksana, pengamat, reflector, dan sebagai pelapor hasil penelitian. Sebagai subyek pemberi tindakan, peneliti bertindak sebagai pengajar atau guru yang bertugas membuat rancangan pelaksana pemberian (RPP) sekaligus menyampaikan bahan ajar yang akan di berikan selama pembelajaran. Sebelum melakukan pengamatan para observer dilatih terlebih dahulu agar memahami materi pengamatan dan model pembelajaran yang akan diterapkan beserta materi yang akan diajarkan pada saat melakukan penelitian.Adapun subjek dalam penelitian ini adalah peserta didik kelas V/B SDN-2 Bukit Tunggal yang berjumlah 21 orang.

Rancangan PTK dalam penelitian ini adalah rangkaian kegiatan yang berurutan dan berkesinambungan yang dicirikan dengan adanya model kerja yang dilakukan peneliti dengan menggunakan siklus-siklus, setiap siklus terdiri dari empat tahapan yaitu: perencanaan tindakan, 
Berdasarkan grafik 1 di atas melalui perbaikan pembelajaran dengan menggunakan media kartu pecahan pada proses pembelajaran Matematika yang dilakukan oleh peneliti di kelas V/B SDN-2 Bukit Tunggal Palangka Raya Tahun Ajaran 2017/2018, menunjukan ada peningkatan aktivitas peserta didik pada siklus I dan siklus II. Berdasarkan grafik 2 di atas, maka dapat diketahui bahwa hasil belajar peserta didik dari data awal sampai pos tes siklus II telah mengalami peningkatan, pada data awal ketuntasan klasikalnya hanya mencapai $33,33 \%$ dengan kategori sangat kurang tercapai, siklus I presentase ketuntasan klasikalnya mencapai $61,90 \%$ dengan kategori tidak tercapai, siklus II ketuntasan klasikalnya lebih meningkat hingga $100 \%$ dengan kategori sangat tercapai.

Berdasarkan hasil penelitian yang diperoleh maka dapat diketahui bahwa dengan menggunakan media kartu pecahan dalam pembelajaran matematika pokok bahasan penjumlahan pecahan dapat meningkatkan aktivitas dan hasil belajar peserta didik.

\section{KESIMPULAN}

1. Aktivitas belajar peserta didik dalam pembelajaran matematika dengan menggunakan model pembelajaran Problem Based Learning (PBL) dan berbantuan meda kartu pecahan pada peserta didik kelas V/B SDN-2 Bukit Tunggal. Berkategori baik.

2. Ada peningkatan hasil belajar matematika dengan menggunakan model pembelajaran Problem Based Learning (PBL) dan berbantuan media kartu pecahan pada peserta didik kelas V/B SDN-2 Bukit Tunggal.

\section{DAFTAR PUSTAKA}

Huda Miftahul, 2013, ModelModel Pengajaran dan Pembelajaran. Yogyakarta: Pustaka Pelajar.

Kartini, N, H, 2017. Penerapan Model Pembelajaran Problem Based Learniang Dengan Metode Debat Terhadap Keterampilan Bertanya Mahasiswa Mata Kuliah Ilmu Kealaman Dasar Universitas Muhammadiyah Palangkaraya. 
Tunas Jurnal Pendidikan Guru Sekolah Dasar, Juni 2019, Volume 4 Nomor 2, (1-8)

ISSN : 2477-6076 